\title{
Biochemical characterization of ratfish (Cbimaera monstrosa) liver oil; cytotoxic and antineoplastic evaluation in cancer cell lines
}

\author{
Ali Mallakin ${ }^{1 *}$, Pankaj Taneja ${ }^{2}$, Kazushi Inoue ${ }^{3}$, Natalie Anne Ward ${ }^{4}$ and Hans-Uwe Dahms $^{5}$ \\ ${ }^{1}$ West Coast Biomedius, Vancouver, British Columbia, Canada \\ ${ }^{2}$ Department of Biotechnology, Sharda University, Uttar Pradesh, India \\ ${ }^{3}$ Department of Pathology, Wake Forest University School of Medicine, Winston-Salem, NC, USA \\ ${ }^{4}$ Department of Biochemistry, Medical College of Wisconsin, Milwaukee, WI, USA \\ ${ }^{5}$ Department of Biomedical Science and Environmental Biology, Kaohsiung Medical University, Kaohsiung, Taiwan, R.O.C.
}

\begin{abstract}
Background: Ratfish liver oil (RLO) with a high abundance of valuable fatty acids, alkylglycerols (AKGs) and their methoxy derivates, is an ancient traditional Scandinavian medicine used to enhance the immune response in immune-related diseases and cancer. AKGs, also known as 1-O-alkyl-sn-glycerols or alkyl-etherlipids, are naturally occurring glyceryl ethers that are abundant in the liver of certain elasmobranch fish species such as ratfish or rabbitfish (Chimaera monstrosa), spiny dogfish (Squalus acanthias) and Greenland shark (Somniosus microcephalus). Shark liver oil (SLO) or AKGs incorporated into pharmaceutical products have been shown to display several in vivo biological efficacies such as stimulation of the immune system and anti-tumor and anti-metastatic activities.
\end{abstract}

Methods: Fatty acids, AKGs, and squalene were isolated from RLO, identified by gas-liquid chromatography (GC), and their purities and quantities were demonstrated. Moreover, cytotoxic and antineoplastic activities of RLO were elucidated using a cell proliferation assay, and the expression of several tumor suppressors and oncogenes were evaluated at both the mRNA and protein levels.

Results: RLO was found to contain a considerable amount of SFA, EPA, DHA and ALA in addition to AKGs and squalene, which have important therapeutic properties. Treatment of MCF7 (human breast cancer) cells with RLO increased the expression of tumor suppressors such as DMP1 (hDMP1, DMTF1) and p53 by 2 to 4 -fold. RLO was shown to elicit its effect by the activation of p53 via an ARF-independent mechanism, causing a direct physical interaction between DMP1 $(\mathrm{DMP} 1 \alpha)$ and $\mathrm{p} 53$. This is similar to the mechanism of action of certain chemotherapy drugs such as doxorubicin, where DMP1 binds to gene regulatory regions in a p53-dependent fashion. This mechanism is initiated when cells receive stress signaling other than ARF-mediated oncogene overexpression.

Conclusions: The present study is the first to provide complete quantitative and qualitative lipid profiling of RLO and its effect on selected tumor suppressor genes and oncogenes. The effect elicited by RLO is similar to that produced by other stressors that accelerate DNA-binding of p53 by DMP1 as a critical mechanism of increasing $\mathrm{p} 53$ activity in response to stress signaling other than oncogenic overexpression. Moreover, the lipid profiling data can be used in future studies to identify the AKGs present in cancer cells and to compare their compositions with those in normal cells.

Abbreviations: AKG: Alkylglycerols; ALA: Alpha-Linolenic Acid; CK: Creatine Kinase; DHA: Docosahexaenoic Acid; DMP1: Cyclin D Binding Myb-Like Protein 1; DMEM: Dulbecco's Modified Eagle's Medium; EPA: Eicosapentaenoic Acid; FA: Fatty Acid; FBS: Fetal Bovine Serum; GAPDH: Glyceraldehyde 3-Phosphate Dehydrogenase; GC: Gas Liquid Chromatography; HDM2: Human Double Minute 2; HER2: Human Epidermal Growth Factor-2; hPRP: Human PlateletRich Plasma; MDM2: Mouse Double Minute 2; MUFA: Monounsaturated Fatty Acid; MW: Molecular Weight; NF- $\kappa B$ : Nuclear Factor- $\kappa B$; PKC: Protein Kinase C; PUFA: Polyunsaturated Fatty Acid; RLO: Ratfish Liver Oil; RT-PCR: Reverse Transcription Polymerase Chain Reaction; SFA: Saturated Fatty Acid; SV: Saponification Value; SLO: Shark Liver Oil; WB: Western Blot; WST-1: Water-Soluble Tetrazolium

\section{Introduction}

Shark liver oil (SLO), which is rich in alkylglycerols (AKGs), squalene, squalamine and other derivatives, has been widely used in Scandinavian countries as a complementary medicine for the treatment of a wide variety of diseases, particularly cancer. The antitumor and immune-boosting efficacies of SLO have been suggested based on the scarcity of tumors in sharks and their ability to resist infection $[1,2]$. AKGs are the main active components in SLO, which have been studied as anti-cancer agents in several clinical trials [3-5]. Moreover, AKGs have been investigated for the treatment of radiationinduced side effects and for their immune-boosting capabilities [3,4]. Experimental studies have demonstrated the ability of AKGs to increase permeability of the blood-brain-barrier and facilitate access of therapeutic drugs to the central nervous system [6,7]. RLO has a

${ }^{\star}$ Correspondence to: Ali Mallakin, West Coast Biomedius, Vancouver, British Columbia, Canada, E-mail: wcbiomed@telus.net

Keywords: ratfish liver oil, fatty acids, alkylglycerols, squalene, DMP1, DMTF1, cancer

Received: December 05, 2018; Accepted: December 14, 2018; Published: December 19, 2018 
lower content of long chain fatty acids than other fish oils and therefore presents a higher resistance to oxidation. One of the most important therapeutic feature of this oil is its outstanding high content of AKGs, which are the ether equivalents of acylglycerols $[8,9]$. AKGs have been a subject of interest, with and much attention, due to their special health-promoting, anticarcinogenic and immunomodulatory effects in animals and humans [10-12].

RLO is extracted and purified from ratfish or rabbitfish (Chimaera monstrosa), an elasmobranch fish species that lives in cold, deep oceans such as the North Atlantic. RLO contains AKGs, squalene, squalamine, lipid-soluble vitamins, and a diverse range of saturated, unsaturated and monounsaturated fatty acids. AKGs are ether-linked glycerols (alkyl-ether-lipids) that include substances such as batyl alcohol, chimyl alcohol, selachyl alcohol and paramecyl alcohol are present in blood producing organs such as the bone marrow, spleen and liver; however, they can also be found in human milk and colostrum. Marine sources of AKGs include the liver oil of certain shark species and ratfish. Several clinical trials have demonstrated the ability of AKGs to support the immune system in a variety of manners [13]. AKGs foster natural responses toward bacteria, fungi, and yeast infections, increase the total antioxidant status of the blood, and help to support the production of certain cytokines such as interleukin 12 (IL-12) and interferon gamma (IFN- $\gamma$ ). IL-12 is an anti-inflammatory cytokine that down regulates, and therefore reduces, the secretion of proinflammatory cytokines including tumor necrosis factor-alpha (TNF- $\alpha$ ) and interleukin-11 (IL-11). Both TNF- $\alpha$ and IL-11 are proteins that contribute to the inflammatory response. AKGs can increase the number of leukocytes, lymphocytes and platelets [14]. IFN- $\gamma$ is released by white blood cells including lymphocytes and macrophages, and is known to possess anti-viral and anti-tumor properties. AKGs have also been shown to have other beneficial effects including hematopoietic support, sperm quality improvement, radiotherapy-induced injury reduction, and anti-tumor and anti-metastasis activities; and have also been used to treat leukemia and solid tumors. In addition to marine sources, AKGs are also synthesized by the human body, with lactating women needing to synthesize higher AKGs levels to meet the requirements of infant development $[15,16]$. The anti-neoplastic effects of AKGs have been documented since the 1950s, following the work of the Swedish physician, Astrid Brohult, who observed that feeding fresh calf bone marrow extracts to children with leukemia raised their white blood cell counts. Brohult and her biochemist husband elucidated the active compounds, which were eventually identified as AKGs, and later she began administering AKGs to patients in an oncology setting. Much earlier, two Japanese scientists without knowing the importance of their discovery, extracted AKGs from deep-water sharks as early as 1922 [17]. Years later, the Brohults published their studies on AKGs treatment of patients with invasive cervical cancer who had received radiation therapy [3-5]. The preliminary data generated from these early efforts shows a high level of efficacy for combating cancer and reducing the toxicity of cancer treatments.

Alkoxyglycerols as ether-linked lipids are much more stable and resistant to cleavage compared with their parent molecules, AKGs (a). In the main lipid species R1 and R2 are ester-linked long-chains and $\mathrm{R} 3$ is ether-linked (Figure 1). During chemical analysis the ester-linked chains of AKGs are removed, leaving the right-hand structure $(b)$ with only an ether-linked alkyl chain, which is more chemically stable for gas chromatography analysis.

Numerous studies have been conducted on the immune action of AKGs in vivo; however, little is known regarding the related gene expression, protein synthesis or in vitro mechanisms by which RLO, a)

b)
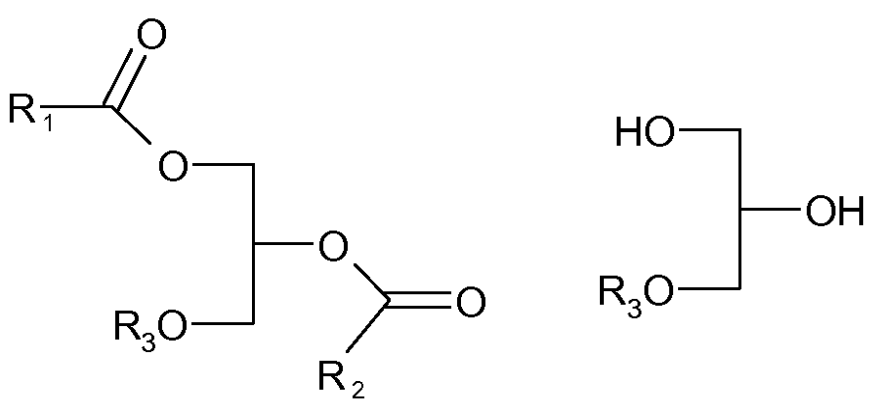

Figure 1. The main lipid species in elasmobranch oils, where R1 and R2 are ester-linked long-chains and R3 is ether-linked. General presentation of a compound from the group of alkylglycerols (a) and alkoxyglycerols $(b)$, in which R1, R2 and R3 are alkyl chains. Alkylglycerol is a compound in which R1, R2 and R3 are alkyl chains, and alkoxyglycerol is a compound in which $R_{3}$ is an alkyl chain.

specifically AKGs and squalene boost the immune system or result in cancer cell death. To better understand the effects of RLO on cancer cells we carried out a complete lipid analysis of RLO, focusing on the role of AKGs in cell proliferation, gene expression and protein synthesis in selected cancer and normal human cell lines.

Our previous studies have identified Dmp1 (cyclin D binding Myblike protein 1; also termed Cyclin-D-binding Myb-like transcription factor 1 (Dmtf1)) as a critical tumor suppressor involved in breast cancer [18-22]. The Dmpl transcription factor acts as a tumor suppressor and transmits oncogenic Ras-Raf signaling to the ARF-p53 pathway leading to p53 stabilization and senescence, and induction of cell cycle arrest $[20,23,24]$. The Ras oncogene has been shown to activate the Dmp1 promoter [24] while physiological mitogens and genotoxic stimuli mediated by NF- $\kappa B$ cause repression [21]. Dmp1 physically interacts with p53 to neutralize the known functions of Mdm2 (or HDM2 in human), namely ubiquitination, nuclear-cytoplasmic transport, and suppression of transport [25-28]. The hDMP1 locus encodes at least three splice variants that includes hDMP $1 \alpha, \beta$, and $\gamma$, all of which have antagonizing functions $[26,29]$. The hDMPla gene is an analog of murine Dmpla, which positively regulates the p19 ${ }^{\text {Arf }}$-p53 pathway [29,30]; however, the hDMP1 $\beta$ and $\gamma$ isoforms lack a DNAbinding domain, and hDMP1 $\beta$ has a dominant-negative function over hDMP1a with respect to ARF induction [29].

We have previously shown that enforced expression of hDMP $1 \beta$ stimulates cell proliferation in a p53-independent fashion, inducing aberrant growth of mammary glands and accelerating tumorigenesis $[26,30]$. Under cellular stresses the tumor suppressor p53 is activated and initiates transactivation of a group of genes involved in cell cycle arrest, apoptosis, DNA repair, or autophagy, and which play crucial roles in the prevention of tumor formation [31,32]. The central regulator of the $\mathrm{p} 53$ pathway is $\mathrm{Mdm} 2$ (HDM2), a protein that inhibits the transcriptional activity, nuclear localization, and protein stability of p53 $[33,34]$. The activity of Mdm2 is negatively regulated by $19^{\text {Arf }}$ in response to oncogenic stress [35]. p14 ${ }^{\mathrm{ARF}}$ directly binds to $\mathrm{Mdm} 2$, thus stabilizing and activating $\mathrm{p} 53$. ARF expression is induced by oncogenic stresses triggered by the overexpression of mutant Ras, c-Myc, E2F1, or HER2 [36]. Conversely, the ARF promoter is repressed by the overexpression of nuclear proteins such as Bmi1, Twist, Tbx $2 / 3$, and Pokemon [36]. The ARF promoter is activated by latent oncogenic signals in vivo, which forces early-stage cancer cells to undergo p53dependent and -independent cell cycle arrest, apoptosis, and/or autophagy, providing a powerful mode of tumor suppression [35,37]. 
In the present study, a qualitative and quantitative analysis of RLO was conducted based on fatty acids, AKGs and squalene composition in the neutral fraction. RLO was selected over SLO, since it has a higher AKG content compared with other fish liver oils, and is a more ancient remedy that appears to have better overall immune-stimulating effects. Moreover, changes in gene expression and protein synthesis following treatment of normal and cancer cells with RLO were determined. The present data reveal that RLO, similar to certain chemotherapy drugs such as doxorubicin, results in ARF-independent activation of p53. This mechanism is mediated by the direct physical interaction between DMP1 (hDMP1) and p53, which occurs when cells receive stress signaling other than the oncogene overexpression governed by ARF (Figure 2). These results indicate that, in addition to antineoplastic and immunomodulatory effects, RLO can be recommended as a suitable nutritional supplement due to its composition of different fatty acids, in particular omega fatty acids, and the hydrocarbon squalene. In particular, we examined the following two hypotheses: I) RLO changes the expression levels of candidate tumor suppressor genes and proteins (particularly in the DMP1 and ARF-p53 pathways) in MCF7 cancer cells; and II). RLO causes an ARF-independent mechanism of p53 activation.

\section{Methods}

\section{Ratfish liver oil}

RatfishOil $^{\bullet}$ (RLO) was supplied by Rosita Real Foods ${ }^{\mathrm{Tx}}$ (Helgeland, Norway), consisting of pure and unprocessed natural oil extracted from the liver of the North Atlantic Ratfish (Chimaera monstrosa). The oil contains a wide spectrum of fatty acids including a considerable amount of omega fatty acids, natural vitamins $\mathrm{A}, \mathrm{D}, \mathrm{E}$ and $\mathrm{K}$, alkylglycerols, squalene and squalamine. The oil was diluted in DMSO or Tyrode's buffer for the preparation of various concentrations. The molarity $(\mathrm{mol} / \mathrm{L})$ was calculated based on its molecular weight, which was determined by obtaining the RLO saponification value (SV) and the use of the formula: $\mathrm{MW}=56,000 / \mathrm{SV}-12.67[38,39]$.

\section{Cell culture}

MDA-MB-231 cells (triple negative breast cancer), TZM-BL cells

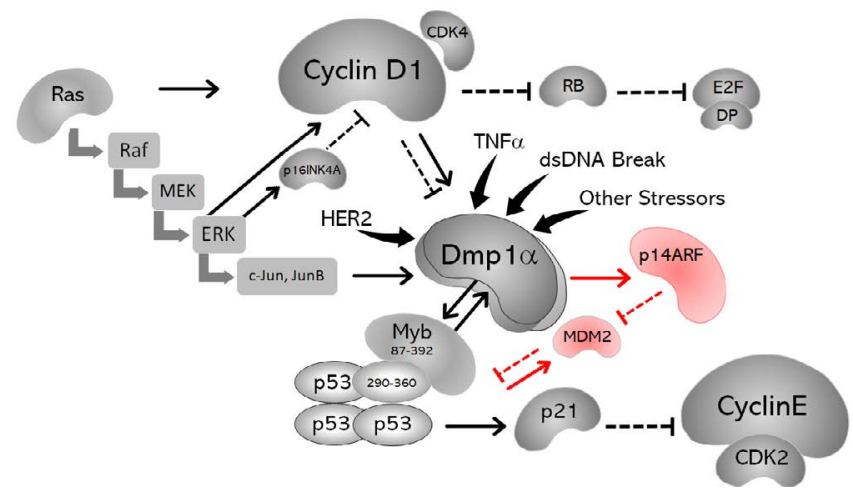

Figure 2. Schematic representation of the findings obtained in the present study and those of previously published data. The DMPI promoter is activated by oncogenic Ras and overexpression of HER2, which subsequently activates the p14 ${ }^{\mathrm{ARF}}$ pathway to induce cell cycle arrest or apoptosis. The DMP1 promoter is also activated by TNF $\alpha$ and dsDNA breaks caused by doxorubicin or etoposide. Dmp $1 \alpha$ can also directly binds to the p53 C-terminus and neutralize all the known functions of $\mathrm{Mdm} 2$ with respect to $\mathrm{p} 53$. This effect is mutually exclusive of DMP $1 \alpha$ binding to DNA; and thus, is independent of ARF. In addition, DMP1 $\alpha$-p 53 binding accelerates DNA binding of p 53 to target genes, which has been shown previously (27). The mechanism by which Dmp1 neutralizes the activity of $\mathrm{Mdm} 2$ indirectly via the regulation of the $A r f$ promoter is shown in red. The three subunits of DMP1, $\alpha, \beta$ and $\gamma$, which overlap with each other, are shown in the center. (derived from HeLa), Ca9-22 cells (oral cancer cells), A549(P20); H1299(P23); H460(P29) cells (lung cancer), MCF-7 cells (breast cancer, National Centre for Cell Science, Pune, India) and MCF-10A cells (normal breast epithelial cells, Pune, India) were cultured as previously recommended [18-22].

\section{Cell proliferation assays}

The Cell Titer 96 Aqueous One solution cell proliferation (MTS) assay (Promega, Madison, WI, USA), the Cell Proliferation Reagent WST-1 assay (Roche, Mannheim, Germany) and the trypan blue exclusion method were used to determine cell proliferation or viability of the selected cell lines. In these assays, cells were seeded in triplicate on 24 - or 96-well plates at a density of $1 \times 10^{3}-1.6 \times 10^{6}$ cells/well in 100 - $500 \mu \mathrm{l}$ Dulbecco's modified Eagle's medium (DMEM), supplemented with either fetal bovine serum (FBS) or human platelet-rich plasma (hPRP), as described previously [40]. Cells were cultured at $37^{\circ} \mathrm{C}, 5 \%$ $\mathrm{CO}_{2}$ for 24 hours.

\section{Trypan blue exclusion assay}

Trypan blue staining was used to examine cells viability following exposure of MCF-7 and MDA-MB-231 breast cancer cell lines to different concentrations of RLO. Cells were trypsinized, resuspended in equal volumes of medium and trypan blue $(0.05 \%$ solution) and counted using a hemocytometer. Trypan blue dye (Invitrogen) exclusion was used to assess cell viability.

\section{MTS colorimetric assay}

Cells were seeded on 96-well plates at a density of $1 \times 10^{3}$ cells/ well in $100 \mu \mathrm{L}$ medium and cultured at $37^{\circ} \mathrm{C}, 5 \% \mathrm{CO}_{2}$. Forty-eight hours later, cells were exposed to different concentrations of RLO (1-4 $\mathrm{mg} / \mathrm{ml}$ ) and subsequently subjected to an MTS assay at time intervals of 1-3 days as indicated. Measurements were made according to the manufacturer's instructions (Promega Corp., Madison, WI, USA). In brief, the recommended amount of MTS reagent was added directly to the cells, which were incubated at $37^{\circ} \mathrm{C}, 5 \% \mathrm{CO}_{2}$ for 3-hour. Metabolic activity was determined as relative colorimetric changes as measured at $490 \mathrm{~nm}$ using a plate reader, obtaining the number of viable cells relative to the control population. The reference was measured at 620 $\mathrm{nm}$ for all dyes. The data were analyzed using Microsoft Excel.

\section{WST-1 cell proliferation assay}

Water-soluble tetrazolium (WST)-1 cell proliferation reagent was purchased from Roche Diagnostics GmbH (Mannheim, Germany). MDA-MB-231 cells and TZM-BL cells were seeded on 24-well plates and cultured for 24 -hour at $37^{\circ} \mathrm{C}, 5 \% \mathrm{CO}_{2}$. Cells were subsequently treated with various concentrations of RLO and incubated for a further 24-hour. Following treatment, the medium was replaced with DMEM containing $0.5 \%$ FBS and $10 \%$ WST-1 reagent and incubated for 1-hour at $37^{\circ} \mathrm{C}, 5 \% \mathrm{CO}_{2}$, and the absorbance was read at $450 \mathrm{~nm}$.

\section{Real-time quantitative PCR}

The expression of several candidate genes DMP1 (DMTF1), p14 ${ }^{\mathrm{ARF}}$, p21 Cip1/WAF1, Caspase3, HER2, and RAS were determined by real-time quantitative PCR TaqMan assays on a CFX 96 Real-Time PCR module (Bio-Rad Laboratories Inc., CA, USA). Values were normalized to the expression of the Gapdh internal control [24]. Average gene expression levels are shown as bar graphs with standard errors. Statistical analyses were conducted using an unpaired t-test. The statistical significance levels are shown by the number of stars: ${ }^{\star} 0.01<p<0.05 ;{ }^{\star \star} 0.001<p$ $<0.01 ;{ }^{* *} p<0.001$. The primer sequences are available upon request. 


\section{Western blotting}

Proteins were extracted in ice-cold EBC lysis buffer containing protease inhibitors $[19,20,40]$. Following gel electrophoresis and transfer to nitrocellulose membranes, proteins were visualized by immunoblotting using affinity-purified polyclonal antibodies against DMP1 (DMTF1, GTX112228, GeneTex, Inc. Irvine, CA), p53 (9282, Cell Signaling Tech, Denver, MA), and p14 ${ }^{\mathrm{ARF}}$ (GTX129903, GeneTex, Inc. Irvine, CA), with GAPDH (D16H11, Cell Signaling Tech, Denver, MA) as an internal control, followed by HRP-conjugated secondary antibodies, and reaction with an enhanced ECL detection kit (GE Health sciences, New Delhi, India). The densitometric analyses were conducted using a TCX color transmission digital densitometer (Tobias Associates, Inc., Ivyland, PA, USA).

\section{Quantitative and qualitative analysis of RLO}

\section{Fatty acid analysis}

The total fatty acid content was analyzed using the MIDI Sherlock System (Marine1 Analysis Package, MIDI, Newark, DE, USA), which involves the use of a base-catalyzed transmethylation procedure, a method equivalent to AOCS Ce 1b-89 (fatty acid composition of marine oils and marine oil esters based on GC analysis). Sherlock uses a sample preparation procedure and gas chromatography (GC) to produce qualitatively and quantitatively reproducible fatty acid composition profiles. The Sherlock MIS provides chromatographic data, integration of analyzed samples, cluster analysis, and pattern recognition searches of databases. The analytical heart of the MIDI Sherlock System is Agilent ChemStation, which provides automated sample analysis and data storage. Peak naming was performed by the Sherlock software and the results were stored as Sherlock data files (MIDI, Newark, USA).

\section{AKG analysis}

A complete qualitative and quantitative analysis of AKGs was performed by Mylnefield Lipid Analysis, Dundee, Scotland, UK.

\section{I) Preparation of lipids extracts}

In duplicate, approximately $20 \mathrm{mg}$ sample was dissolved in 0.1 M potassium hydroxide $/ 90 \%$ aqueous ethanol. The samples were hydrolyzed by heating to $50^{\circ} \mathrm{C}$ in a heat block for 3-hour followed by the addition of $200 \mathrm{ml}$ internal standard solution $(0.6137 \mathrm{~g}$ 1-O-heptadecylglycerol in $250 \mathrm{ml}$ methanol). Subsequently, $2 \mathrm{ml}$ of $5 \%$ aqueous sodium chloride solution and $2 \mathrm{~mL}$ iso-hexane/ether $(1: 1, \mathrm{v} / \mathrm{v})$ were added sequentially, and the layers were allowed to separate. A short $(3 \mathrm{~cm})$ column of anhydrous sodium sulphate was used to remove any remaining water. The samples were extracted a further twice with $2 \mathrm{ml}$ iso-hexane/ether $(1: 1, \mathrm{v} / \mathrm{v})$. The solvent was evaporated using nitrogen or a centrifugal evaporator. Trimethylsilyl esters were prepared by addition of $100 \mathrm{ml}$ silylation reagent to the reaction containing the glycerol ethers. The vial was then sealed and heated in an oven at $105^{\circ} \mathrm{C}$ for 15 minutes. The trimethylsilyl esters were analyzed directly by GC on a non-polar column as described below (Mylnefield Lipid Analysis, Dundee, UK.).

\section{II) Gas chromatography}

Gas-liquid chromatography (GC) of the total lipid extracts (trimethylsilyl esters) was performed using a gas chromatograph with split injection and an FID (Agilent 7890 Series, Agilent Technologies, Edinburgh, UK), on an HP-5, 5\% phenyl methyl siloxane column (Agilent Technologies, Edinburgh, UK), which is an excellent non-polar general-purpose column. The air flow $(450 \mathrm{ml} / \mathrm{min})$ and hydrogen flow
( $40 \mathrm{ml} / \mathrm{min}$ ) were adjusted to provide a maximum detector response. The detector temperature was set to $320^{\circ} \mathrm{C}$ and was maintained within $0.5^{\circ} \mathrm{C}$ by means of a special temperature controller (supplied with the instrument). The temperatures of the on-column injector $\left(320^{\circ} \mathrm{C}\right)$ and the detector mode makeup flow were set to constant (Mylnefield Lipid Analysis, Dundee, UK).

\section{Statistical analyses}

Comparisons of gene expression and cell proliferation were performed using a two-tailed t-test. For differences between rates, the statistical significance was set at $p<0.05$.

\section{Results}

\section{Quantitation of the fatty acids in RLO}

The total number of fatty acids determined by GC following saponification, methylation, and extraction of RLO in the present study is summarized in Table 1 . Considerable numbers of fatty acids and AKGs were observed in the oil profile, which contribute to the antineoplastic and bioactivity of RLO. Myristic acid (1.28\%), pentadecylic acid $(0.23 \%)$, palmitic acid $(12.56 \%)$, margaric acid $(0.44)$ and stearic acid $(5.38 \%)$ were some of the main saturated fatty acids (Table 1). The major portion of unsaturated fatty acids consisted of oleic acid (33.3\%), gondoic acid (6.11\%), linoleic acid (1.10\%), eicosapentaenoic acid (EPA; $4.52 \%)$, and docosahexaenoic acid (DHA; $5.16 \%$ ) (Table 1).

In general, the proportions of saturated and polyunsaturated fatty acids in RLO were similar, at $20.15 \%$ and $20.06 \%$, respectively (Tables 1 and 2). A marked difference was observed in the proportion of monounsaturated fatty acids, which was twice that of either the saturated or polyunsaturated fatty acid content $(57.69 \%$ monosaturated; Table 2). The fatty acids present in the smallest amounts include the branched fatty acids (1.17\%) and others $(0.93 \%)$. RLO was found to contain $57.69 \%(376.6 \mathrm{mg} / \mathrm{g})$ monounsaturated fatty acids, which is substantially higher than that previously reported in SLO (w/w 29.9\%) [41].

The lipid composition of RLO can be affected by numerous factors, such as the fishing period, location, and types or availability of food. With the exception of its AKG content, RLO can be regarded as an excellent source of monounsaturated and polyunsaturated fatty acids (MUFAs and PUFAs). Oleic acid (C18:1 w9c) was the predominant MUFA in RLO (217.395 mg/g or 33.30\%) (Tables 1 and 2), and previous studies have also reported considerable amounts of oleic acid in the liver oil of Ratfish, Greenland Shark and Gray Dogfish. The present study shows that RLO has considerable and equal amounts of saturated fatty acids (SFAs) and PUFAs with docosahexaenoic acid (C22:6 w3c) being predominant (33.674 mg/g or 5.16\%). Two of the PUFAs, eicosapentaenoic acid (EPA) and docosahexaenoic acid (DHA), have previously been reported to be important in the prevention of cardiovascular diseases, inflammatory disorders, and as good nutritional supplements. SFAs, such as palmitic and stearic acids, are used as a source of energy and cellular building blocks, and for protein modification, and regulation of gene transcription.

Large quantities of EPA (20:5 w3c), DHA (22:6 w3c), and other omega- 3 fatty acids, such as $\alpha$-linolenic acid (ALA), present in RLO have in common a carbon-carbon double bond in the $\omega-3$ position and are nutritionally essential. The amount of omega- 6 fatty acids in RLO was almost twice that of other PFUs, and omega- 9 fatty acids were present in the highest amount $(262.61 \mathrm{mg} / \mathrm{ml})$ among other omega 
Table 1. Fatty acid composition of ratfish liver oil (RLO).

\begin{tabular}{|c|c|c|c|}
\hline \multirow{2}{*}{ Common names of fatty acids } & \multirow{2}{*}{ Systematic IUPAC name } & \multicolumn{2}{|c|}{ concentration } \\
\hline & & $\mathbf{w} / \mathbf{w}^{\mathbf{a}}$ & $\% \mathbf{o}^{\mathrm{b}}$ \\
\hline Myristic acid (C14:0) & Tetradecanoic acid & 8.379 & 1.28 \\
\hline Pentadecylic acid (15:0) & Pentadecanoic acid & 1.531 & 0.23 \\
\hline 13-Methylmyristic acid (15:0 iso) & 13-Methyltetradecanoic acid & 1.049 & 0.16 \\
\hline Fatty acid $(15: 4 \mathrm{w} 3 \mathrm{c})^{c}$ & $(3 \mathrm{Z}, 6 \mathrm{Z}, 9 \mathrm{Z}, 12 \mathrm{Z})-3,6,9,12$-Pentadecatetraenoic acid & 1.358 & 0.21 \\
\hline Palmitic acid (16:0) & Hexadecanoic acid & 82.015 & 12.56 \\
\hline Isopalmitic acid (16:0 iso) & 14-Methylpentadecanoic acid & 1.164 & 0.18 \\
\hline Cis-11-Palmitoleic acid (16:1 w5c) & (11Z)-11-Hexadecenoic acid & 0.677 & 0.10 \\
\hline Palmitoleic acid (16:1 w7c) & (9Z)-9-Hexadecenoic acid & 47.808 & 7.32 \\
\hline Margaric acid (17:0) & Heptadecanoic acid & 2.875 & 0.44 \\
\hline Isomargaric acid (17:0 iso) & 15-Methylhexadecanoic acid & 3.437 & 0.53 \\
\hline Anteisomargaric acid (17:0 anteiso) & 14-Methylhexadecanoic acid & 2.001 & 0.31 \\
\hline Fatty acid $(17: 1 \text { anteiso w7c })^{c}$ & (9Z)-13-Methyl-9-Hexadecenoic acid & 6.076 & 0.93 \\
\hline Stearic acid (18:0) & Octadecanoic acid & 35.151 & 5.38 \\
\hline Cis-13-Oleic acid (18:1 w5c) & (13Z)-13-Octadecenoic acid & 3.152 & 0.48 \\
\hline Cis-12-Oleic acid (18:1 w6c) & (12Z)-12-Octadecenoic acid & 1.153 & 0.18 \\
\hline Cis-Vaccenic acid (18:1 w7c) & (11Z)-11-Octadecenoic acid & 46.750 & 7.16 \\
\hline Oleic acid (18:1 w9c) & (9Z)-9-Octadecenoic acid & 217.395 & 33.30 \\
\hline Linoleic acid (LA) (18:2 w6c) & $(9 Z, 12 Z)-9,12-$ Octadecadienoic acid & 7.178 & 1.10 \\
\hline Gamma-linolenic acid (18:3 w6c) & $(6 Z, 9 Z, 12 Z)-6,9,12-$-Octadecatrienoic acid & 1.628 & 0.25 \\
\hline Stearidonic acid (SDA) (18:4 w3c) & $(6 \mathrm{Z}, 9 \mathrm{Z}, 12 \mathrm{Z}, 15 \mathrm{Z})-6,9,12,15$-Octadecatetraenoic acid & 5.271 & 0.81 \\
\hline Arachidic acid (20:0) & Icosanoic acid & 1.583 & 0.24 \\
\hline Fatty acid $(20: 1 \mathrm{w} 6 \mathrm{c})^{c}$ & (15Z)-15-Heneicosenoic acid & 14.421 & 2.21 \\
\hline Gondoic acid (20:1 w9c) & (11Z)-11-Icosenoic acid & 39.916 & 6.11 \\
\hline Dihomo-gamma-linolenic acid (20:3 w6c) & $(8 Z, 11 Z, 14 Z)-8,11,14-$ Icosatrienoic acid & 1.793 & 0.27 \\
\hline Eicosatetraenoic acid (20:4 w3c) & $(8 \mathrm{Z}, 11 \mathrm{Z}, 14 \mathrm{Z}, 17 \mathrm{Z})-8,11,14,17-$ Icosatetraenoic acid & 4.330 & 0.66 \\
\hline Arachidonic acid (20:4 w6c) & $(5 Z, 8 Z, 11 Z, 14 Z)-5,8,11,14-$ Icosatetraenoic acid & 6.965 & 1.07 \\
\hline Eicosapentaenoic acid (20:5 w3c) & $(5 Z, 8 Z, 11 Z, 14 Z, 17 Z)-5,8,11,14,17$-Icosapentaenoic acid & 29.536 & 4.52 \\
\hline Fatty acid $(21: 3 \mathrm{w} 6 \mathrm{c})^{c}$ & $(9 Z, 12 Z, 15 Z)-9,12,15-H e n e i c o s a t r i e n o i c ~ a c i d ~$ & 5.190 & 0.80 \\
\hline Heneicosapentaenoic acid (HPA) (21:5 w3c) & 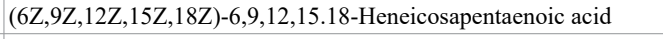 & 2.917 & 0.45 \\
\hline Erucic acid $(22: 1 \mathrm{w} 9 \mathrm{c})$ & (13Z)-13-Docosenoic acid & 3.586 & 0.55 \\
\hline Docosadienoic acid (22:2 w6c) & $(13 Z, 16 Z)-13,16-$ Docosadienoic acid & 15.462 & 2.37 \\
\hline Fatty acid $(22: 3 \mathrm{w} 3 \mathrm{c})^{c}$ & $(14 Z, 17 Z, 20 Z)-14,17,20-$ Docosatrienoic acid & 2.286 & 0.35 \\
\hline Docosapentaenoic (22:5 w3c) & $(7 Z, 10 Z, 13 Z, 16 Z, 19 Z)-7,10,13,16,19-$ Docosapentaenoic acid & 11.870 & 1.82 \\
\hline Osbond acid (22:5 w6c) & $(4 Z, 7 Z, 10 Z, 13 Z, 16 Z)-4,7,10,13,16-$ Docosapentaenoic acid & 1.511 & 0.23 \\
\hline Docosahexaenoic acid $(22: 6 \mathrm{w} 3 \mathrm{c})$ & $(4 Z, 7 Z, 10 Z, 13 Z, 16 Z, 19 Z)-4,7,10,13,16,19$-Docosahexaenoic acid & 33.674 & 5.16 \\
\hline Nervonic acid (24:1 w9c) & (15Z)-15-Tetracosenoic acid & 1.714 & 0.26 \\
\hline Total fatty acids & & $652.8 \mathrm{mg} / \mathrm{g}$ & $99.98 \%$ \\
\hline
\end{tabular}

${ }^{a}$ Quantitation of FAME in w/w (mg/g of RLO).

${ }^{b}$ Percentage of each chemical

${ }^{c}$ Fatty acids with no common name

Table 2. Concentration and percentage of each types of saturated, monounsaturated and polyunsaturated fatty acids in RLO.

\begin{tabular}{|c|c|c|}
\hline \multirow{2}{*}{ Type of fatty acid } & \multicolumn{2}{|c|}{ Concentration } \\
\hline & $\mathbf{w} / \mathbf{w}^{a}$ & $\%^{b}$ \\
\hline Saturated & 131.53 & 20.15 \\
\hline Monounsaturated & 376.57 & 57.69 \\
\hline Polyunsaturated & 130.97 & 20.06 \\
\hline Branched & 7.65 & 1.17 \\
\hline Others & 6.08 & 0.93 \\
\hline Total fatty acids & $652.8 \mathrm{mg} / \mathrm{g}$ & $100 \%$ \\
\hline
\end{tabular}

${ }^{a}$ Quantitation of FAME in w/w (mg/g of RLO).

${ }^{b}$ Percentage of each group of SAF, MUFA, PUFA and branched fatty acids.

fatty acids (Table 3 ). Oleic acid, as a monounsaturated omega- 9 fatty acid, had the highest proportion among the omega- 9 fatty acids, at $217.40 \mathrm{mg} / \mathrm{ml}$ (Table 1 ). Other omega-9 fatty acids such as gondoic acid (20:1 w9c), erucic acid (22:1 w9c), and nervonic acid (24:1 w9c) were also found in RLO at $39.92 \mathrm{mg} / \mathrm{ml}, 3.6 \mathrm{mg} / \mathrm{ml}$, and $1.7 \mathrm{mg} / \mathrm{ml}$, respectively (Table 1).

\section{Quantitation of AKGs}

In the present study, RLO was found to contain AKGs with 1420 carbon atoms in their side chains. Both saturated and unsaturated alcohols or ether-linked glycerols were present, with selachyl alcohol (18:1) making up approximately $57 \%$ of the AKG content (Table 4). 
Table 3. Different types of omega fatty acids.

\begin{tabular}{|c|c|c|}
\hline \multirow{2}{*}{ Omega fatty acid } & \multicolumn{2}{|c|}{ Concentration } \\
\cline { 2 - 3 } & $\mathbf{w} / \mathbf{w}^{\boldsymbol{a}}$ & $\mathbf{\%}^{\boldsymbol{b}}$ \\
\hline EPA $(20: 5 \mathrm{w} 3 \mathrm{c})$ & 29.536 & 4.52 \\
\hline DHA $(22: 6 \mathrm{w} 3 \mathrm{c})$ & 33.674 & 5.16 \\
\hline Other Omega-3s & 28.031 & 4.29 \\
\hline Omega-6 & 55.302 & 8.47 \\
\hline Omega-9 & 262.61 & 40.23 \\
\hline Saturated & 131.53 & 20.15 \\
\hline Other fatty acids & 112.11 & 17.17 \\
\hline Total fatty acids & $\mathbf{6 5 2 . 8} \mathbf{~ m g} / \mathbf{g}$ & $\mathbf{9 9 . 9 9 \%}$ \\
\hline
\end{tabular}

a) Quantitation of FAME in w/w (mg/g of RLO)

b) Percentage of each group of omega fatty acids

Table 4. Alkylglycerol composition of ratfish liver oil (RLO).

\begin{tabular}{|c|c|c|}
\hline $\begin{array}{c}\text { Common name of } \\
\text { Alkylglycerol }\end{array}$ & Chemical name & $\begin{array}{c}\text { Concentration } \\
\mathbf{w} / \mathbf{w}^{a}\end{array}$ \\
\hline Myristyl glyceryl ether (C14:0) & 1-O-tetradecylglycerol & 1.0 \\
\hline AKG C14:1 ${ }^{b}$ & 1-O-tetradecenylglycerol & 0.0 \\
\hline AKG 14br & Methyl-tridecylglycerol & 0.0 \\
\hline AKG 15:0 & 1-O-pentadecylglycerol & 1.0 \\
\hline Chimyl alcohol (16:0) & 1-O hexadecylglycerol & 13.0 \\
\hline AKG 16:1 & 1-O-hexadecenylglycerol & 9.0 \\
\hline AKG 17:1 & 1-O-heptadecenylglycerol & 4.0 \\
\hline Batyl alcohol (18:0) & 1-O-octadecylglycerol & 23.0 \\
\hline Selachyl alcohol 18:1(n-9) & 1-O-octadec-9-enylglycerol & 91.0 \\
\hline Paramecyl alcohol 18:1(n-7) & 1-O-octadec-11-enylglycerol & 13.0 \\
\hline AKG 20:1 & 1-O-eicosenylglycerol & 4.0 \\
\hline Squalene & Squalene & 16.0 \\
\hline Total Alkylglycerols & & $\mathbf{1 5 9} \mathbf{~ m g / g}$ \\
\hline
\end{tabular}

a) Quantitation of AKGs in w/w (mg/g of RLO)

b) Alkylglycerols with no common name

c) Squalene is not included in the total AKGs

These AKG species mostly contain 18:1 as 1-O-alkyl chains with lesser amounts of O-16:0, O-16:1, O-17:1 and O-18:0. It was found that the four major AKG species, chimyl alcohol (16:0), batyl alcohol (18:0), selachyl alcohol 18:1(n-9), and paramecyl alcohol 18:1(n-7), accounted for approximately $88 \%$ of the total AKGs in RLO (Table 4). The composition and relative abundance of other AKG species in RLO were as follows: 1-O hexadecylglycerol $(13 \mathrm{mg} / \mathrm{g}), 1-\mathrm{O}$-hexadecenylglycerol ( $9 \mathrm{mg} / \mathrm{g}), 1-\mathrm{O}-\mathrm{h}$ eptadecenylglycerol $(4 \mathrm{mg} / \mathrm{g}), 1-\mathrm{O}-\mathrm{octadecylglycerol}$ (23 mg/g), 1-O-octadec-9-enylglycerol (91 mg/g), and 1-O-octadec11 -enylglycerol $(13 \mathrm{mg} / \mathrm{g})$.

\section{Quantitation of squalene}

It is known that SLO, and specifically RLO, are recommended as nutritional and therapeutic supplements due to their high squalene content, the concentration of which was calculated to be $16 \mathrm{mg} / \mathrm{g}$ in the RLO analyzed in the present study. Squalene, a C30 H50 (C30: 6n-omega 2) all-trans-isoprenoid, with six unconjugated double bonds (Figure 3), is typically found in deep-sea shark species and certain terrestrial plants [42]. Squalene is a triterpene and an intermediate in the sterol biosynthesis pathway in plants and animals, and the richest known source is shark liver oil. Squalene is the main component of human skin surface polyunsaturated lipids, and shows certain advantages for the skin as an emollient and antitumor compound. This triterpene has also been found to have protective activity against several carcinogens; and due to the double-bond structure, functions as a strong anti-oxidant, anticancer agent, and natural antibiotic [42].

\section{Cell proliferation and viability}

In general, the cell proliferation and viability assays showed no changes in cell number upon incubation with RLO. Viability of MCF7 cancer cells was examined by the trypan blue exclusion method and compared with normal MCF-10A breast epithelial cells, which was inconclusive. The viability of Ca9-22, A549(P20), H1299(P23), and H460(P29) cell lines was determined by an MTS assay following a 24-, 48-, and 72-hour treatment with RLO at concentrations of 1-4 $\mathrm{mg} / \mathrm{ml}$. The amount of colored aqueous formazan product was used to determine cell viability. No significant reduction in viable cells was observed at these concentrations or time ranges. Subsequently, a WST-1 assay was used for spectrophotometric quantitation of MDA-MB-231 and TZM-BL cell proliferation and viability. It was determined that different concentrations of RLO may exert differential effects on cell growth; however, there was no obvious cell death at the above concentrations. Each cell viability assay used in the present study has its own set of advantages and disadvantages; however, in general, none showed any significant decrease in cancer cell numbers following exposure to 1-4 mg/ml of RLO in 72-hour. However, higher concentrations of RLO and longer exposure resulted in cancer cell death. Cell line and tissue specificity are other subjects which can be studied further in the future.

\section{mRNA expression levels}

mRNA expressions levels of genes involved in cell proliferation, tumorigenesis, and apoptosis were evaluated. DMP1, p21, p14 ${ }^{\mathrm{ARF}}, \mathrm{p} 53$, Caspase-3, HER2, and Ras were selected as candidate transcriptional target genes due to their contribution to cell cycle arrest and apoptosis (DMP1, p14 ${ }^{\mathrm{ARF}}$, and $\mathrm{p} 53$ ), cell cycle progression ( $\mathrm{p} 21$ ), and cell proliferation and apoptosis (Caspase-3, HER2, and Ras). These genes, some of which are novel Dmp1 targets, were validated in the present study. Statistically significant differences in expression are shown as stars $\left({ }^{\star} p<0.05,{ }^{\star \star} 0.001<p<0.05\right.$ and $\left.{ }^{* * *} p<0.001\right)$. The maximum gene expression for all the selected genes was achieved at $4 \mathrm{mg} / \mathrm{ml}$ RLO in MCF-7 breast cancer cells, with the highest increase (3.97-fold or 297\%; $p<0.001$ ) being $p 53$ (Figure 4). Increases in Caspase-3 and DMP1 (DMTF1) mRNA expression levels in MCF-7 cells were 3.26fold (226\%; $p<0.001)$ and 3.12-fold $(212 \% ; p<0.001)$, respectively, following a 72 hours exposure to RLO (Figure 4). The p14 ${ }^{\mathrm{ARF}}$ and $\mathrm{p} 21$ mRNA expression levels were upregulated to $112 \%(p<0.001)$ and

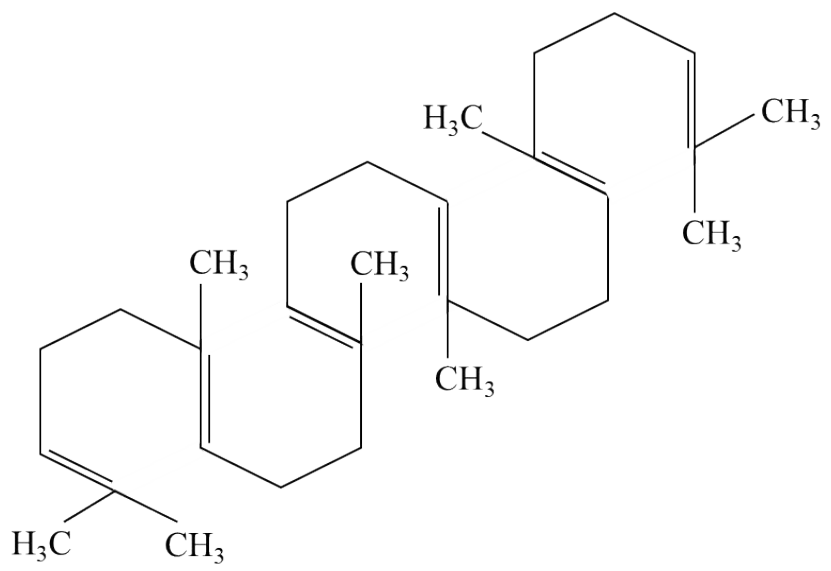

Figure 3. Squalene chemical structure.

Squalene is a natural dehydrotriterpenic hydrocarbon $\left(\mathrm{C}_{30} \mathrm{H}_{50}\right)$ with six double bonds, known as an intermediate in the biosynthesis of phytosterol or cholesterol in plants and animals. 
$188 \%(0.001<p<0.05)$ of the control cell lines (Figure 4). In contrast, no significant induction was seen in the selected oncogenes (HER2 and Ras); instead, HER2 was significantly downregulated by $50 \%$ as compared with the levels in normal MCF-10A breast epithelial cells, but Ras showed no significant changes (Figure 4).

Changes in the expression levels of the selected tumor suppressor genes in normal breast epithelial cells (MCF-10A) were much less pronounced than those in MCF-7 breast cancer cells following incubation with RLO. The major changes included upregulation of p53 (134\%), Caspase-3 (117\%), DMP1 (110\%), and p21 (97\%). With the exception of slight changes in Ras, variations in the selected oncogenes were not significant (Figure 4). Comparison of gene expression between MCF-7 and MCF-10A cells following incubation with RLO showed that the cancer cells had $163 \%$ higher p53 levels, $100 \%$ higher Caspase-3, p14 ${ }^{\mathrm{ARF}}$, and DMP1 levels, and 91\% higher p21 levels (Figure 4).

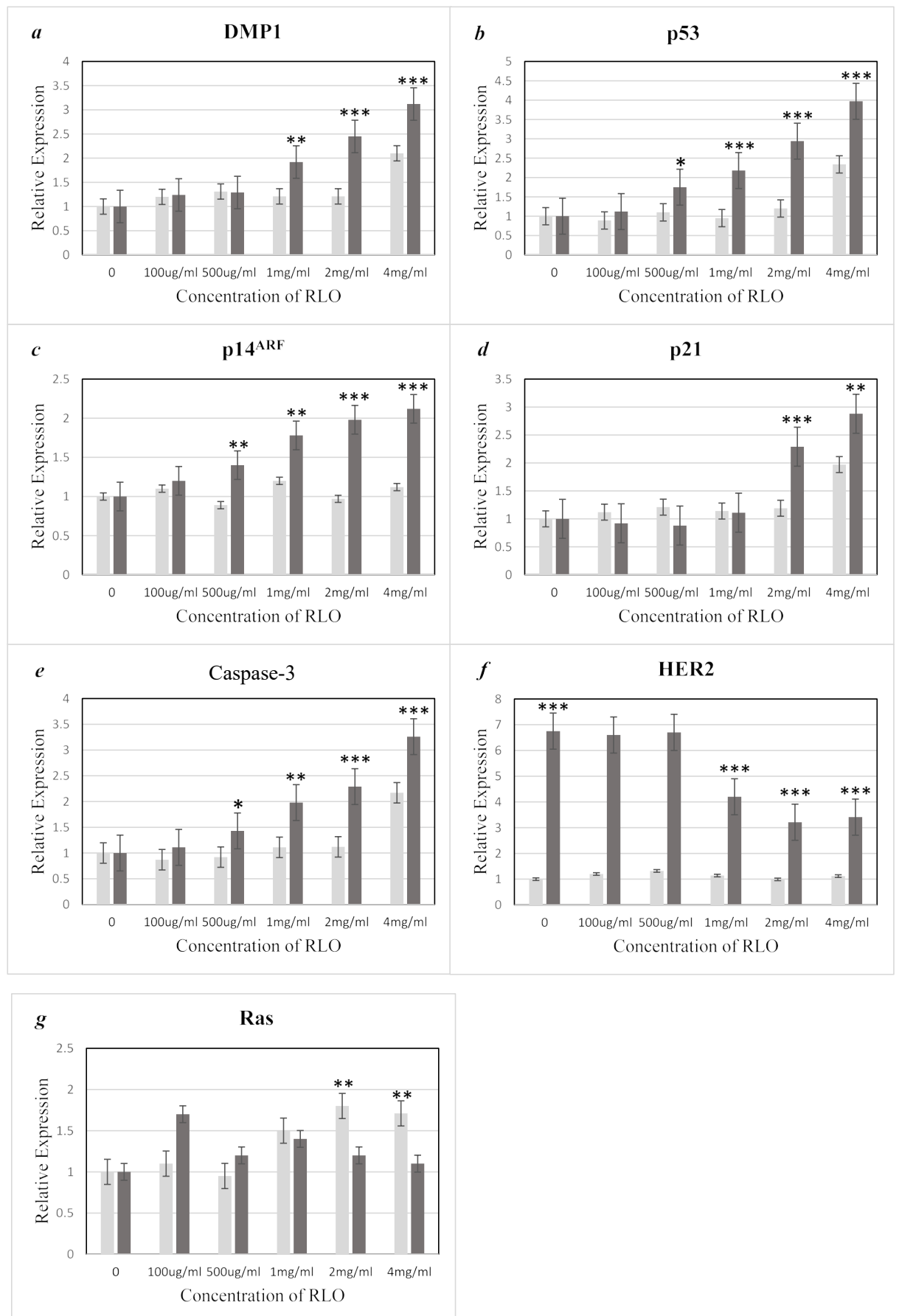

Figure 4. Relative mRNA expression levels of $D M P 1, p 14^{A R F}$, p53, p21, HER2, and Ras.

RNA was extracted from normal breast cells (MCF10A) and breast cancer cells (MCF7), and quantitative RT-PCR analysis of target mRNA was performed following a 72-hour exposure to different concentrations of RLO. The error bars for MCF10A and MCF7 cells data represent experimental variations in the real-time PCR analysis. The data are expressed as the mean \pm SE of three independent experiments for each mRNA $(a-g)$. Normal breast cells (MCF10A $\square$ ) and breast cancer cells (MCF7 $\square$ ). 


\section{Protein expression levels}

Western blotting analysis was performed to verify that the changes in mRNA expression could also be observed at the protein level. In MCF-7 cells, the protein expression levels of DMP1 (DMTF1), p14 ${ }^{\mathrm{ARF}}$, and p53 were evaluated following a 72-hour exposure to RLO (Figure 5). DMP1 was increased by almost 4 -fold and p53 was increased by 2.5 -fold, which appeared to be independent of p14 ${ }^{\mathrm{ARF}}$ activity, since its protein expression levels remained similar. The ARF-independent mechanism of p53 activation is likely caused by a direct physical interaction between DMP1 and p53. RLO at a concentration of 0.5-2 $\mathrm{mg} / \mathrm{ml}$ causes stimulation of $\mathrm{p} 53$ that is independent of $\mathrm{p} 14^{\mathrm{ARF}}$ in MCF7 cells; however, the activation of DMP1 and p53 in MCF-10A cells is not significant since no considerable changes can be found at other doses. The ARF-independent mechanism of p53 activation is likely caused by a direct physical interaction between DMP1 and p53. RLO at a concentration of $0.5-2 \mathrm{mg} / \mathrm{ml}$ caused stimulation of p53 that is independent of $\mathrm{p} 14^{\mathrm{ARF}}$ in MCF-7 cells; however, the activation of DMP1 and p53 in MCF-10A cells was not significant, since no considerable changes were found at other doses. The protein expression levels of p14 ${ }^{\mathrm{ARF}}$ appeared to be consistent and are upregulated following a 72hour exposure to $4 \mathrm{mg} / \mathrm{ml}$ RLO. In MCF-10A cells, there was a transient increase in $\mathrm{p} 53$ protein expression with increasing concentrations of RLO up to $2 \mathrm{mg} / \mathrm{ml}$ after a 72-hour exposure, followed by a decline when DMP1 was downregulated (Figure 5a). p14 ${ }^{\mathrm{ARF}}$ protein expression appeared to be consistent up to $2 \mathrm{mg} / \mathrm{ml}$, but increased slightly at $4 \mathrm{mg} /$ $\mathrm{ml}$, which is consistent with a decrease in DMP1 and p53 levels. This

$\boldsymbol{a}$

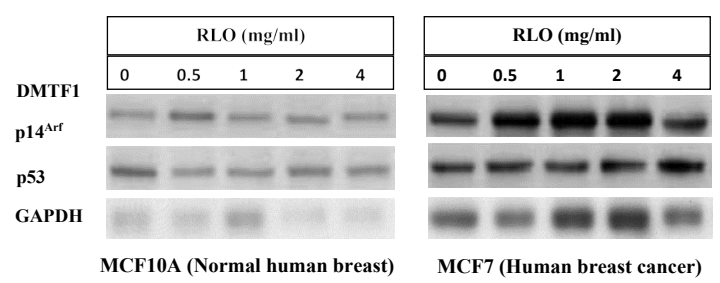

$\boldsymbol{b}$

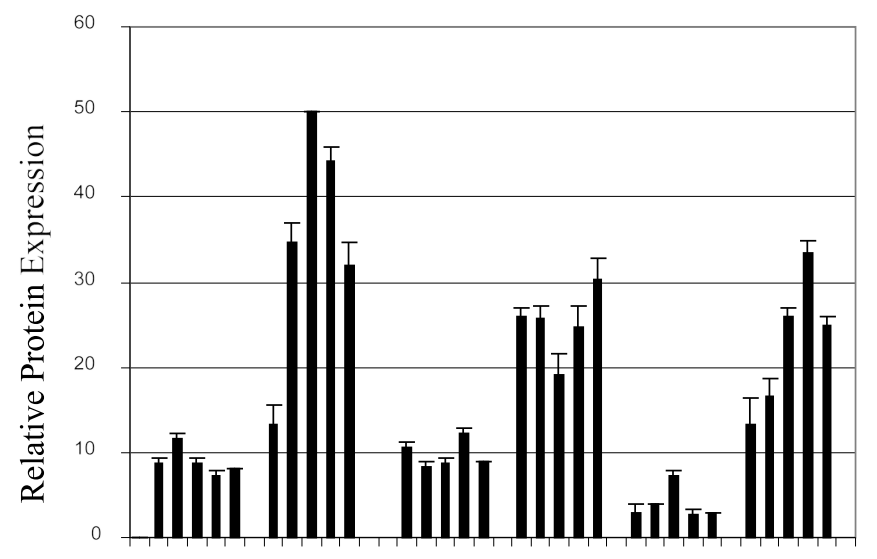

DMTF 1

pl4ARF

p53

MCF-10A MCF-7 MCF-10A MCF-7 MCF-10A MCF-7

Figure 5. Protein expression levels of DMP1 (DMTF1), p14 ${ }^{\mathrm{ARF}}$, and 553 in MCF10A and MCF7 cells.

Equal protein loading was verified by comparison with GAPDH. Top panel, western blots of DMTF1, p14 ARF and p53 (a) Histogram of densitometric analysis of the western blots shown above $(b)$. Bars represent the mean \pm SE optical density normalized to the control samples for each group $(\mathrm{n}=3), p<0.05$. feedback regulation between $\mathrm{p} 53$ and ARF, as we will discuss later, have been described previously. Densitometric analysis was performed and the values were normalized to GAPDH levels (Figure 5b). Collectively, these results indicate that DMP1, p14 ${ }^{\mathrm{ARF}}$, and $\mathrm{p} 53$ protein expression levels were much higher in MCF-7 breast cancer cells than in normal MCF-10A breast epithelial cells. In the present study, western blotting data confirmed the observations obtained with RT-PCR.

\section{Discussion}

To date, there are no inclusive data available regarding the qualitative, quantitative, and biochemical characteristics of bioactive compounds in the liver oil of ratfish from the Norwegian sea, where this species has the highest abundance. RLO is a rich source of fatty acids and contains high and equal amounts of saturated fatty acids (SFAs) and monounsaturated fatty acids (MUFAs). The amount of polyunsaturated fatty acids (PUFAs) is more than twice the amount of SFAS and MUFAs combined. RLO has a significant proportion of alkylglycerols, squalene and squalamine indicating that it has multiple in vitro and in vivo properties and can potentially be used as a nutritional supplement to stimulate the immune response and activate genes responsible for tumor suppression. Short term exposure of the selected cancer cell lines to RLO did not show significant cytotoxic activity; however, more detailed molecular studies showed its effect on the expression of tumor suppressors and oncogenes at both the mRNA and protein levels. Studying the activity of DMP1 is useful since it initiates two independent mechanisms that act together to neutralize the activity of HDM2 $[27,28]$. One mechanism acts directly through the regulation of p53 stabilization and the second acts indirectly through the regulation of the $A R F$ promoter. Moreover, haplo-insufficiency of DMP1 for tumor suppression often results in tumors that retain one allele of DMP1 [18], making modulatory effects of this gene more likely.

Recent studies have focused on certain bioactive components of SLO, with AKGs and squalene being two of the most cited. AKGs are believed to be helpful in the maintenance of health and the treatment of several diseases via different mechanisms [3-8], having been reported to kill tumor cells indirectly and reduce the side effects of chemotherapy and radiation treatment [3-6]. Preliminary studies have suggested that AKGs may have anti-tumor effects in animal models, which has been attributed to their ability to protect cell membranes [43]; however, their effects in humans require further study. AKGs in SLO are believed to strengthen the immune system in humans by stimulating macrophages and activating specific proteins involved in the signal transduction response to many hormones and growth factors [44]. Biological activities of AKGs include interaction with hormone and growth factor receptors [45] or inhibition of protein kinase $\mathrm{C}$ (PKC), which has a high activity in breast tumors $[44,46,47]$.

Other compounds present in RLO, such as squalene and squalamine, have also been promoted for their anti-cancer and antibacterial activities [48]. The molecular weight of squalene is higher than that of EPA or DHA, and therefore infuses deeper, quicker and more effectively into cells [48]. Squalene, as a natural antioxidant, plays a key role in lowering blood cholesterol, increasing the antitumor activity of chemotherapeutic agents, inhibiting cancer progression, and increasing the efficiency of the immune system [42,48]; therefore, the presence of squalene in RLO would improve its therapeutic and nutraceutical values. In the present study, the squalene concentration in RLO was calculated to be $16.0 \mathrm{mg} / \mathrm{g}$ (Table 4). As a natural and highly unsaturated aliphatic hydrocarbon, squalene is also present in cod liver oil, palm oil, olive oil and other vegetable oils [49]. Related 
studies have shown that squalene, AKGs, and certain fatty acids present in liver oil exert anticancer effects [50].

The present cell viability data following exposure of different cancer cell lines (MDA-MB-231, TZM-BL, Ca9-22, A549(P20), H1299(P23), $\mathrm{H} 460$ (P29), and MCF-7) to increasing doses of RLO were inconclusive. This is in accordance with certain previous studies that have shown the indirect stimulation of the immune system and neoplastic capacity of AKGs, rather than a direct action, which requires the involvement of AKGs in cell membranes. According to previous reports, the anticancer effects of AKGs may be due to their capacity to activate macrophages and increase the production of certain cytokines (IL12 and IFN- $\gamma$ ) [51]. The recruitment and activation of macrophages are essential for primary antitumor defense [51], although IFN- $\gamma$, a T-cell derived lymphokine, inhibits a wide number of cancer cells via its immunomodulatory properties [52]. Previous reports revealed that SLO, specifically Greenland Shark (Somniosus microcephalus) liver oil increase IFN- $\gamma$ with subsequent enhancement of cellular immunity and increase in CD8+ lymphocytes accompanied by a decrease in tumor size. In contrast, another study using liver oil extracted from deep sea shark (Echinorhinus brucus) showed a dose-dependent cytotoxic effect in neuroblastoma cells (SH-SY5Y) following a 48-hour treatment [49]. The cytotoxic effect, as shown by an MTT assay, resulted in over $90 \%$ cell death at concentrations of 5-100 $\mu$ g, which can be attributed to the high concentration of squalene (38.4\%) in this oil [49]. Squalene has been promoted as having cell protective effects, which may also reduce the side effects of chemotherapy [53]. In another study using the plating efficiency method to assess the effect of AKGs on human ovarian, breast, and prostate carcinoma cell lines, there was a dramatic reduction in prostate cancer cell numbers even at relatively low concentrations of AKGs $(0.1$ and $0.5 \mathrm{mg} / \mathrm{ml})$. Flow cytometry showed an increase in the percentage of apoptotic ovarian and prostate carcinoma cells, although the breast carcinoma cells became mainly necrotic following exposure to commercially available Ecomer ${ }^{\star}$ (Ecomer ${ }^{\star}$ SLO containing $20 \%$ AKGs and 3\% methoxy derivatives at a dose of $0.1 \mathrm{mg} / \mathrm{ml}$ ) [54].

The fatty acids identified following saponification of RLO in the present study are summarized in Tables 1 and 2. Palmitic acid (12.5\%), myristic acid (1.3\%), and stearic acid (5.4\%) were the major saturated fatty acids identified in RLO. The major portion of unsaturated fatty acids included oleic acid (33.3\%), EPA and DHA (4.52\%; 5.16\%), and omega- 6 and -9 fatty acids $(8.5 \% ; 40.2 \%)$ (Table 1 and 2). This is in accordance with previous reports on ratfish and certain shark liver oils [55]. RLO can be regarded as an excellent source of PUFAs, of which EPA and DHA, are known to be important in the prevention and treatment of heart diseases [56]. EPA and DHA are particularly beneficial to human health; and many investigations have shown that omega-3 polyunsaturated fatty acids not only lower the risk of cardiovascular disease but can also inhibit the development of cancer and stimulate immunity [57]. AKGs and squalene are the major components that provide the anticancer activity of RLO; however, it is well known that PUFAs have also cytotoxic action on cancer cells.

Previous investigations have shown that Dmp1 physically interacts with p53 and antagonizes all activities of Mdm2 (or HDM2), such as p53 ubiquitination, nuclear-cytoplasmic transportation, and transactivation of target genes [27,28]. Dmp1- p53 binding does not affect the binding of p53 to target genes or Mdm2; however, binding of Dmp1 to p53 is considered to be mutually exclusive [27]. Dmp1 has a unique function, since it directly binds and activates the Arf promoter and simultaneously physically interacts with p53 [58]. Dmp1 positively regulates p53 in terms of stabilization and nuclear localization [27]; thus, Dmp1 is a critical antagonist of Mdm2 in the regulation of p53 activity. Dmp1 is known for its role as a critical transcriptional activator of Arf (p19 $9^{\mathrm{Arf}}$ in mice or p14 $4^{\mathrm{ARF}}$ in human) [23,35,37]. ARF stabilizes nucleoplasmic p53 by binding to and sequestering Mdm2 in the nucleolus or by directly inhibiting the ubiquitin ligase activity of $\mathrm{Mdm} 2[59,60]$. Inhibition of the ubiquitination and nuclear export of p53 by Dmp1 is considered to be ARF-independent, since these processes have been shown to occur in cells in which p14 $4^{\mathrm{ARF}}$ has been knocked down or deleted [27].

\section{Conclusion}

The present data reveals that RLO similar to certain chemotherapy drugs such as doxorubicin, results in ARF-independent activation of p53. This mechanism is mediated by the direct physical interaction between DMP1 (DMTF1) and p53, which occurs when cells receive stress signaling other than the oncogene overexpression governed by ARF (Figure 2). These results indicate that, in addition to antineoplastic and immunomodulatory effects, RLO can be recommended as a good nutritional supplement due to its content of different fatty acids, in particular omega fatty acids, and the hydrocarbon squalene. Our study is valuable for identifying marine-based oil therapeutic mediators without side effects, which commonly occur with most current cancer drugs. However, further studies in animals and humans are required to prove the efficacy of the application of RLO as a potential preventive and treatment agent in clinical practice. RLO has the potential to be used for different clinical purposes, including the stimulation of immunological defences and anti-tumor and anti-metastatic activities, in conjunction with chemotherapy or as an alternative therapy. The present study also suggests that Chimaera monstrosa liver oil can play a role in the development of novel strategies for the prevention and treatment of specific cancers. Previous studies and our present data generate compelling evidence for further evaluation of this oil as a preventive regimen that can be used for the maintenance of healthy body functions and for the treatment of cancer. We suggest that ratfish liver oil is a suitable mixture of natural products and is a candidate for the purpose of cancer prevention and therapy with the need for further study.

\section{Acknowledgments}

This study was funded by West Coast Biomedius and contributions from a number of interested sponsors. We thank Drs. Guangchao Sui and, Hsueh-Wei Chang for their helpful discussion and sharing some of their findings. We also thank MIDI, US and Mylnefield Lipid Analysis, James Hutton Limited, UK for their efforts in analyzing the RLO for its lipid content.

\section{Availability of data and materials}

The data analyzed during the present study are available from the corresponding author upon reasonable request.

\section{Declaration of interest}

The authors declare no conflicts of interest. The authors alone are responsible for the content and writing of the paper.

\section{Author contributions}

Concept development, design, and drafting of the manuscript: AM. Acquisition of data: AM and PT. Statistical analysis: AM. Editorial: NAW. Critical review and revision of the manuscript: AM, PT, KI, $\mathrm{NAW}$, and HUD. AM, PT and KI performed the analysis and conduct 
interpretation of the data. All authors read and approved the final manuscript.

\section{Funding}

This study was funded by West Coast Biomedius and contributions from a number of interested sponsors.

\section{Consent for publication}

All authors have reviewed and consented to publication of the paper.

\section{Competing interests}

The authors declare that they have no competing interests.

\section{References}

1. Dosay-Akbulut M (2006) The determination of the specific characteristics on the immunosurveillance against to cancer formation in elasmobranches. Int $J$ Cancer Res 2: $119-123$.

2. Davidson BC, Rottanburg D, Prinz W, Cliff G (2007) The influence of shark liver oils on normal and transformed mammalian cells in culture. In Vivo 21: 333-337. [Crossref]

3. Brohult A, Brohult J, Brohult S, Joelsson I (1979) Effect of alkoxyglycerols on the frequency of fistulas following radiation therapy for carcinoma of the uterine cervix. Acta Obstet Gynecol Scand 58: 203-207. [Crossref]

4. Brohult A, Brohult J, Brohult S (1978) Regression of tumour growth after administration of alkoxyglycerols. Acta Obstet Gynecol Scand 57: 79-83. [Crossref]

5. Brohult A, Brohult J, Brohult S, Joelsson I (1986) Reduced mortality in cancer patients after administration of alkoxyglycerols. Acta Obstet Gynecol Scand 65: 779-785. [Crossref]

6. Hülper P, Veszelka S, Walter FR, Wolburg H, Fallier-Becker P, et al. (2013) Acute effects of short-chain alkylglycerols on blood-brain barrier properties of cultured brain endothelial cells. Br J Pharmacol 169: 1561-1573. [Crossref]

7. Erdlenbruch B, Kugler W, Schinkhof C, Neurath H, Eibl H, et al. (2005) Bloodbrain barrier opening with alkylglycerols: Biodistribution of 1-O-pentylglycerol after intravenous and intracarotid administration in rats. $J$ Drug Target 13: 143-150. [Crossref]

8. Guney AA (2002) Synthesis of controlled-release products insupercritical medium. AIChE J 48: 856-866.

9. Pinault M, Guimaraes C, Couthon H, Thibonnet J, Fontaine D, et al. (2018) Synthesis of Alkyl-Glycerolipids Standards for Gas Chromatography Analysis: Application for Chimera and Shark Liver Oils. Marine Drugs 16: 101. [Crossref]

10. Pugliese PT, Jordan K, Cederberg H, Brohult J (1998) Some biological actions of alkylglycerols from shark liver oil. J Altern Complement Med 4: 87-99. [Crossref]

11. Andreesen R (1988) Ether lipids in the therapy of cancer. Prog Biochem Pharmacol 22: 118-131. [Crossref]

12. Pédrono F, Martin B, Leduc C, Le Lan, J, Saïag B, et al. (2004) Natural alkylglycerols restrain growth and metastasis of grafted tumour in mice. Nutr Cancer 48: 64-69. [Crossref]

13. Mitre R, Etienne M, Martinais S, Salmon H, Allaume P, et al. (2005) Humoral defence improvement and haematopoiesis stimulation in sows and offspring by oral supply of shark-liver oil to mothers during gestation and lactation. Br J Nutr 94: 753-762. [Crossref]

14. Ngwenya BZ, Foster DM (1991) Enhancement of antibody production by lysophosphatidylcholine and alkylglycerol. Proc Soc Exp Biol Med 196: 69-75. [Crossref]

15. Hallgren B, Niklasson A, Stallberg G, Thorin H (1974) On the occurrence of 1-O-alkylglycerols and 1-O-(2-methoxyalkyl) glycerols in human colostrum, human milk, cow's milk, sheep's milk, human red bone marrow, red cells, blood plasma and a uterine carcinoma. Acta Chem Scand B 28: 1029-1034. [Crossref]

16. Embleton ND (2013) Early nutrition and later outcomes in preterm infants. World Rev Nutr Diet 106: 26-32. [Crossref]

17. Tsujimoto M, Toyama Y (1922) Ueber die unverseif-baren Bestandteile (hoheren
Alkohole) der Haifish- und Rochen-leberole. I Chemische Umschau 29: 27-9.

18. Inoue K, Zindy F, Randle DH, Rehg JE, Sherr CJ (2001) Dmp1 is haplo-insufficient for tumor suppression and modifies the frequencies of Arf and p53 mutations in Mycinduced lymphomas. Genes Dev 15: 2934-2939. [Crossref]

19. Mallakin A, Taneja P, Matise LA, Willingham MC, Inoue K (2006) Expression of Dmp1 in specific differentiated, nonproliferating cells and its regulation by E2Fs. Oncogene 25: 7703-7713. [Crossref]

20. Mallakin A, Sugiyama T, Taneja P, Matise LA, Frazier DP, et al. (2007) Mutually exclusive inactivation of DMP1 and ARF/p53 in lung cancer. Cancer Cell 12: 381-394. [Crossref]

21. Taneja P, Mallakin A, Matise LA, Frazier DP, Choudhary M, et al. (2007) Repression of Dmp1 and Arf transcription by anthracyclins: critical roles of the NF-kappaB subunit p65. Oncogene 26: 7457-7466. [Crossref]

22. Inoue K, Wen R, Rehg JE, Adachi M, Cleveland JL, et al. (2000) Disruption of the ARF transcriptional activator DMP1 facilitates cell immortalization, Ras transformation, and tumorigenesis. Genes Dev 14: 1797-1809. [Crossref]

23. Inoue K, Roussel MF, Sherr CJ (1999) Induction of ARF tumor suppressor gene expression and cell cycle arrest by transcription factor DMP1. Proc Natl Acad Sci US A 96: 3993-3998. [Crossref]

24. Sreeramaneni R, Chaudhry A, McMahon M, Sherr CJ, Inoue K (2005) Ras-Raf-Arf signaling critically depends on the Dmp1 transcription factor. Mol Cell Biol 25: 220232. [Crossref]

25. Inoue K, Fry EA, Frazier DP (2016) Transcription factors that interact with p53 and Mdm2. Int J Cancer 138: 1577-1585. [Crossref]

26. Inoue K, Fry EA (2016) Aberrant splicing of the DMP1-ARF-MDM2-p53 pathway in cancer. Int J Cancer 139: 33-41. [Crossref]

27. Frazier DP, Kendig RD, Kai F, Maglic D, Sugiyama T, et al. (2012) Dmp1 physically interacts with p53 and positively regulates p53's stabilization, nuclear localization, and function. Cancer Res 72: 1740-1750. [Crossref]

28. Kendig RD, Kai F, Fry EA, Inoue K (2017) Stabilization of the p53-DNA Complex by the Nuclear Protein Dmp1 $\alpha$. Cancer Invest 35: 301-312. [Crossref]

29. Tschan MP, Federzoni EA, Haimovici A, Britschgi C, Moser BA, et al. (2015) Human DMTF1ß antagonizes DMTF1a regulation of the p14ARF tumor suppressor and promotes cellular proliferation. Biochim Biophys Acta 1849: 1198-1208. [Crossref]

30. Maglic D, Stovall DB, Cline JM, Fry EA, Mallakin A, et al. (2015) DMP1 $\hat{I}^{2}$, a splice isoform of the tumour suppressor DMP1 locus, induces proliferation and progression of breast cancer. J Pathol 236: 90-102. [Crossref]

31. Menendez D, Inga A, Resnick MA (2009) The expanding universe of p53 targets. Nat Rev Cancer 9: 724-737. [Crossref]

32. Bieging KT, Mello SS, Attardi LD (2014) Unravelling mechanisms of p53-mediated tumour suppression. Nat Rev Cancer 14: 359-370. [Crossref]

33. Sullivan KD, Galbraith MD, Andrysik Z, Espinosa JM (2018) Mechanisms of transcriptional regulation by p53. Cell Death Differ 25: 133-143. [Crossref]

34. Vousden KH, Prives C (2009) Blinded by the Light: The Growing Complexity of p53. Cell 137: 413-431. [Crossref]

35. Ozenne P, Eymin B, Brambilla E, Gazzeri S (2010) The ARF tumor suppressor: structure, functions and status in cancer. Int J Cancer 127: 2239-2247. [Crossref]

36. Inoue K, Mallakin A, Frazier DP (2007) Dmp1 and tumor suppression. Oncogene 26 4329-4335. [Crossref]

37. Sherr CJ, Bertwistle D, DEN Besten W, Kuo ML, Sugimoto M, et al. (2005) p53Dependent and -independent functions of the Arf tumor suppressor. Cold Spring Harb Symp Quant Biol 70: 129-137. [Crossref]

38. Singhal RS, Kulkarni PR (1990) Effect of puffing on oil characteristics of Amaranth (Rajgeera) seeds. Journal of the American Oil Chemists 'Society 67: 952-954.

39. Talebi AF, Tabatabaei M, Chisti Y (2014) BiodieselAnalyzer: a user-friendly software for predicting the properties of prospective biodiesel. Biofuel Research Journal 1: 5557.

40. Inoue K, Sherr CJ (1998) Gene expression and cell cycle arrest mediated by transcription factor DMP1 is antagonized by D-type cyclins through a cyclin-dependent-kinaseindependent mechanism. Mol Cell Biol 18: 1590-1600. [Crossref] 
41. Bakes MJ, Nichols PD (1995) Lipid, fatty acid and squalene composition of liver oil from six species of deep-sea sharks collected in southern Australian waters. Comp Biochem Physiol B 110: 267-275.

42. Ko TF, Weng YM, Chiou RY (2002) Squalene content and antioxidant activity of Terminalia catappa leaves and seeds. J Agric Food Chem 50: 5343-5348. [Crossref]

43. Deniau AL, Mosset P, Pedrono F, Mitre R, Bot DL, et al. (1987) Multiple Beneficial Health Effects of Natural Alkylglycerols from Shark Liver Oil. Mar Drugs 8: 21752184. [Crossref]

44. Heymans F, Da Silva C, Marrec N, Godfroid JJ, Castagna M (1987) Alkyl analogs of diacylglycerol as activators of protein kinase C. FEBS Lett 218: 35-40. [Crossref]

45. Benveniste J, Vargaftig BB (1983) Platelet-activating factor: An ether lipid with biological activity. In Ether Lipids: Biochemical and Biomedical Aspects. In: Mangold HK, Paltauf F (Eds.) Academic Press: New York, NY, USA 355-376.

46. Warne TR, Buchanan FG, Robinson M (1995) Growth-dependent accumulation of monoalkylglycerol in Madin-Darby canine kidney cells. Evidence for a role in the regulation of protein kinase. C J Biol Chem 270: 11147-11154. [Crossref]

47. O’Brian C, Vogel VG, Singletary SE, Ward NE (1989) Elevated protein kinase C expression in human breast tumor biopsies relative to normal breast tissue. Cancer Res 49: 3215-3217. [Crossref]

48. Nakagawa M, Yamaguchi T, Fukawa H, Ogata J, Sohtaro Komiyama S, et al. (1985) Potentiation by squalene of the cytotoxicity of anticancer agents against culture mammalian cells and murine tumor. Jpn J Cancer Res 76: 315-320. [Crossref]

49. Venugopal V, Kumaran AK, Chatterjee NS, Kumar S, Kavilakath S, et al. (2016) Biochemical Characterization of Liver Oil of Echinorhinus brucus (Bramble Shark) and Its Cytotoxic Evaluation on Neuroblastoma Cell Lines (SHSY-5Y). Scientifica 6294030 .
50. Fernández Ó, Vázquez L, Reglero G, Torres CF (2013) Discrimination against diacylglycerol ethers in lipase-catalysed ethanolysis of shark liver oil. Food Chem 136: 464-471. [Crossref]

51. Ringenbach L, Bohbot A, Tiberghien P, Oberling F, Feugeas O (1998) Polyethyleniminemediated transfection of human monocytes with the IFN-gamma gene: an approach for cancer adoptive immunotherapy. Gene Ther 5: 1508-1516. [Crossref]

52. Ucer U, Scheurich P, Bartsch H, Berkovic D, Ertel C, et al. (1987) Specific membrane receptors for human interferon-gamma (IFN-gamma). Behring Inst Mitt 88-97. [Crossref]

53. Günes EF (2013) Medical Use of Squalene as a Natural Antioxidant. MÜSBED 3: 220228

54. Krotkiewski M, Przybyszewska M, Janik P (2003) Cytostatic and cytotoxic effects of alkylglycerols (Ecomer). Med Sci Monit 9: PI131-135. [Crossref]

55. Hallgren B, Larsson S (1962) The glyceryl ethers in the liver oils of elasmobrach fish Lipid Res 3: 31-33.

56. Mohebi-Nejad A, Bikdeli B (2014) Omega-3 supplements and cardiovascular diseases. Tanaffos 13: 6-14. [Crossref]

57. Donatella D'Eliseo D, Velotti F (2016) Omega-3 Fatty Acids and Cancer Cell Cytotoxicity: Implications for Multi-Targeted Cancer Therapy. J Clin Med 5:15. [Crossref]

58. Braithwaite AW, Del Sal G, Lu X (2006) Some p53-binding proteins that can function as arbiters of life and death. Cell Death Differ 13: 984-993. [Crossref]

59. Kruse JP, Gu W (2009) Modes of p53 regulation. Cell 137: 609-622. [Crossref]

60. Sherr CJ, Weber JD (2000) The ARF/p53 pathway. Curr Opin Genet Dev 10: 94-99. [Crossref]

Copyright: (C2018 Mallakin A. This is an open-access article distributed under the terms of the Creative Commons Attribution License, which permits unrestricted use, distribution, and reproduction in any medium, provided the original author and source are credited. 